\title{
Learning from experience: creating sustainable urban greenspaces from brownfield sites
}

\author{
G. Sellers, T. R. Hutchings \& A. J. Moffat \\ Environmental and Human Science Division, Forest Research, UK
}

\begin{abstract}
Russia Dock Woodland Park and Bow Creek Ecology Park (formerly Limmo Peninsular Ecology Park) were created by the London Docklands Development Corporation (LDDC) on brownfield sites in London. The original designs failed in part (Russia Dock) or in full (Bow Creek) to be sustainable. This paper reviews their history and development and highlights the lessons that could be learned. Bow Creek Ecology Park (Grid Reference: TQ391812) is a 2.5 ha greenspace in London Docklands. The design was ambitious consisting of six separate ecology zones from chalk grassland to fenland maintained by a complex sluice and wind powered water pumping system. Russia Dock Park (20 ha) is in Southwark (Grid Reference: TQ361798) where derelict wharf areas were utilised to create a wetland ecosystem surrounded by fast growing woodland. Water levels and flow were maintained by a sophisticated pumping system. The main failings at Bow Creek were that the wind pump system could not maintain the wetlands. Habitat areas were also small, so succession became difficult to prevent and the habitats began to merge. This was compounded by the lack of long-term funding available to maintain this restoration, or staff with the skills to run such a complex design. Similarly at Russia Dock, the pumping system, and thus the wetland ecosystem, failed and a general decline followed. In 2002, an improvement programme redeveloped the park on a more sustainable scale, improving the woodland planting scheme and simplifying the original water habitats. This study demonstrates that public consultation, the creation of low maintenance water pumping systems, and the provision of long-term aftercare programmes made during the planning stages of development can make a considerable difference to the sustainability of new greenspace containing wetland features.

Keywords: sustainable, greenspace, brownfield, woodland, ecology, Bow Creek, Russia Dock, wetland, ecology park.
\end{abstract}




\section{Introduction}

The overall aim of this case study was to investigate the history of two brownfield sites that were turned into greenspace and parkland in the second half of the twentieth century by the London Docklands Development Agency (LDDC).

Both parks were expensively developed with complex landscape design plans. Both failed to live up to their original design ideals, fell into decline and had to be redeveloped again in this decade. In neither case, as far as can be ascertained, was there any community consultation as part of the original development planning process. Subsequently at both sites, a second redevelopment, following community consultations was undertaken. At Russia Dock, this led to a design that improved the woodland and open space areas of the park while simplifying the wetland and pond areas. At Bow Creek, which eventually had to be closed for health and safety reasons, the complex water features have been removed and replaced with seasonal wetlands and a pond which do not require pumping. The general layout of the park was simplified, with expensive raised decked walkways removed and normal tarmac paths put in their place. Both these redesigns should make the parks more sustainable in the longer term because they are less expensive and complex to maintain, have fewer mechanical features, such as pumps and wind turbines which malfunction, and are able to be run by rangers rather than by more specialist trained personnel.

Bow Creek was developed as an 'Ecology Park'. This concept originated in the Netherlands in the 1950s and represents the creation of several different habitats in an urban area so that urban inhabitants can experience and learn from them without having to go to the countryside and visit them individually. Their primary aim is therefore educational, especially for urban schools and colleges [1]. However, maintaining numbers of artificial habitats by preventing natural succession occurring and the preservation of artificial habitats within small areas can be expensive and labour intensive. The smaller the artificial habitats become, the more expensive and difficult this is [2]. Although Bow Creek was defined as an Ecology Park, there was never the long-term financial or professional resources put in place to maintain it adequately [1]. Furthermore, the poor design and quality of construction materials used hastened its demise as an educational resource.

Russia Dock is located in Southwark and is part of the Surrey Docks redevelopment that was begun by the LDDC in the late 1970s. It is a linear greenspace development of around 20 ha, (fig. 1), which was formerly the Grand Surrey Inner Docks [3]. Some of the park is densely wooded with trees planted in the late 1970 s and early 1980 s to a 'naturalistic' landscape design. The main species were fast growing trees such as alder, willow and poplar, supplemented with more recent plantings of slower growing climax trees such as oak and beech. Other parts of the park open out into grass areas and the main paths follow the old wharf edges. Most of the dock was filled in but some was left to form water features, such as ponds, with interconnecting water ducts and streams. Water levels and flow were maintained by a complex water pumping 
system, but for a number of years most of these areas have been left to silt up so that they now form areas that are only wet in the winter [4]. There have been no recorded contamination issues associated with this site.

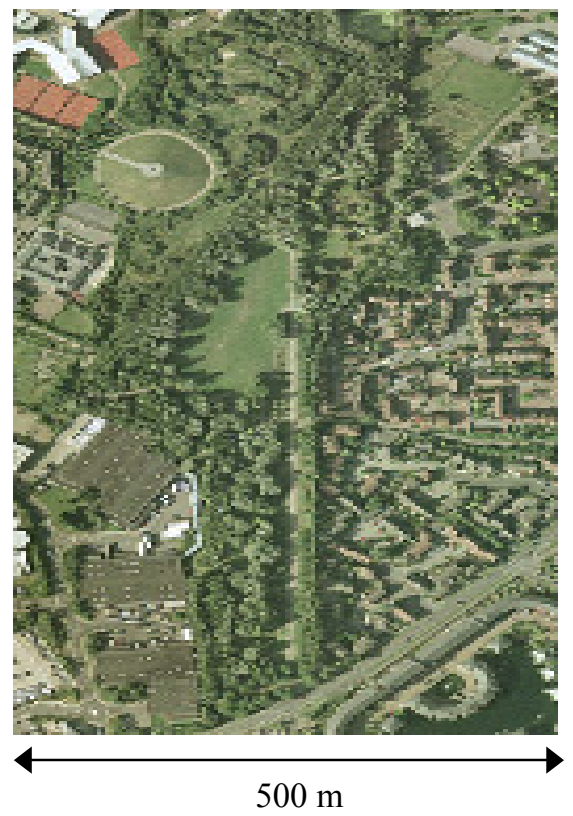

Figure 1: Aerial photograph of Figure 2: Russia Dock Park.

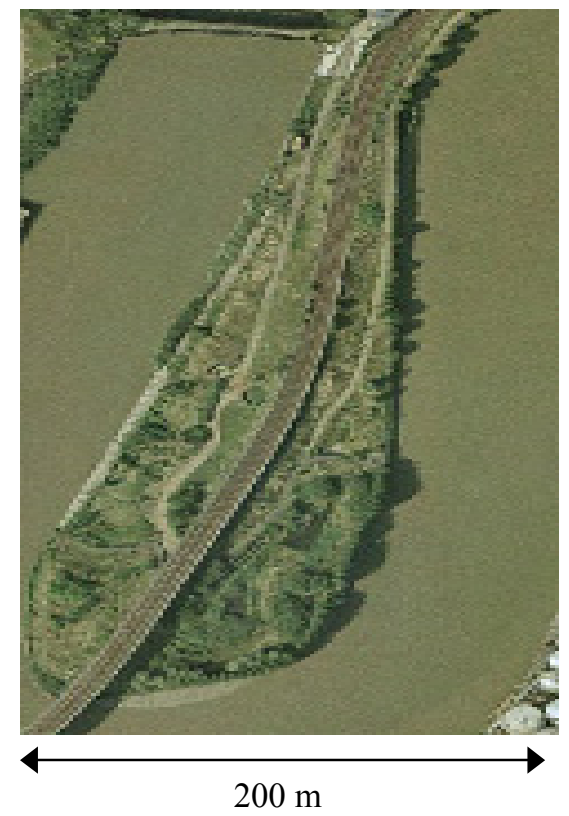

Aerial photograph of Bow Creek Park.

Bow Creek, a former railway yard, fig 2, was developed in 1996 when it was named the Limmo Peninsular Ecology Park. There were contaminated soils on the site but these were covered by a $200 \mathrm{~mm}$ layer of imported topsoil in 1991 as part of the development of the Docklands Light Railway (DLR) flyover, which bisects the park. Later reports commissioned by the LDDC [6] suggested that the land on the west side of the flyover could contain slightly elevated levels of mercury, so an extra $400 \mathrm{~mm}$ of topsoil was added there during park construction. The park was created with six small ecosystems which were designed as an educational tool for local schools and groups as well as being a valuable, if small, piece of greenspace in an area where it is lacking.

Both parks have had problems associated with them. By reviewing their history and analysing the problems that occurred, lessons on how to avoid similar situations in the future can be drawn. 


\section{Russia Dock}

\subsection{Developmental history}

Russia Dock consists of the area formerly known as the Grand Surrey Inner Docks which were constructed from 1696. Previously, the land behind the old village of Rothehythe had been wet marshland unsuitable for farming. Rothehythe had become a centre for shipbuilding and the new docks, including the area now known as Russia Dock, became an extension of this. By the $19^{\text {th }}$ century, the docks were handling grain, timber, cheese and bacon trades together with being a base for the Arctic whaling fleet [6]. As ships got bigger the docks became less capable of handling them and the docks were closed in 1969. In 1978, the LDDC filled in the docks with unconsolidated ex-construction material. Most of the area was designated for housing and commercial development but Russia Dock was restored as an area of greenspace and handed over to Southwark Council in 1982 [7].

\subsection{0-2002}

Originally the park was to have been designed as a formal London Park but this concept was abandoned in favour of a less formal open space and woodland scheme [7]. Although there was no soil on site, there were quantities of silt from the bottom of the docks, which was removed and dried out. This was mixed with imported topsoil to create the growing medium for the park [7]. The park was laid out in blocks of intensively planted fast growing woodland punctuated by pathways connecting the adjoining housing areas. At its centre, the park opens out into an amenity greenspace, fig 1 [3]. Incorporated into the design was a complex system of streams, ponds and created wetlands which were to be maintained by pumps [4]. However, by 1986 the park and especially the water features had declined. A number of problems had become apparent and as early as 1986, just four years after completion, P. Jackson [8] commented:

" the site [Russia Dock]was handed back to the Borough [London Borough of Southwark] for maintenance. At this stage, the problem of expertise and resources required to manage the water features became apparent having never been addressed at the design stage. Following the drowning of a child, there was an unwillingness to make the water feature work. The full implications of managing a man made water feature, and maintaining water quality and circulation, became very critical. The result is that the problems of the water feature remain unsolved and a scar on the landscape."

After the drowning, a management decision was made to allow the water feature to dry up in places in order to lower the water level [8]. M. Pearson [9] makes the further comment that by 1999 : 
"...the interesting situation in 1986 has continued to manifest to the point whereby the tragic event of the drowning of a child still determines the strategy today for the maintenance of the water feature. And as a result of a non intervention strategy the landscape of the water feature and that which surrounds it has been allowed to deteriorate."

This shows us that, even as early as 1986, the park was in decline, the complexity of running the water feature had become critical and expertise to maintain it was not present. The situation continued to decline until 2002.

\subsection{2 to present day: sustainable redevelopment}

In 2002, $£ 350000$ was assigned to the redevelopment of Russia Dock after years of decline and undermanagement [4]. A report on the park and a proposed management plan were commissioned from Voelker Consultants [3]. They identified a number of areas of concern. For example, the open water system had been vandalised, had silted up and fallen into disrepair leading to stagnant surface water. After years of underfunding, the general infrastructure of the park had also fallen into disrepair, with pathways overgrown and bridges, lighting and railings falling into decay. The three timber bridges crossing the water bodies needed to be replaced and the two steel bridges were in need of refurbishment.

As a result of this report, a major redevelopment programme was initiated. Around $£ 40000$ was spent on an urgent tree thinning programme to remove the decaying poplars and willow which had become dangerous and spindly because they had never been thinned out in the 1980s. A programme was instituted to gradually replace poplars with slower growing climax species such as beech and oaks, which were not specified in the original design specification [4].

The process of allowing most of the water features to green over was continued and they have duly become seasonal which improves their conservation value. However, there has been some repair and redevelopment of a few of the ponds and water conduits. Water is now pumped between them, which has allowed the return of fish to some of the ponds. Pond redevelopment is on a much more manageable scale and is far less complex than the original installation and therefore easier to maintain physically and financially [4].

New paths were put in and the old paths restored to make access and movement around the park easier. Infrastructure was also improved with more seats and better lighting [4]. The new, more robust infrastructure, the thinning of trees and the replacement of the poplar trees, together with the partially restored, simplified water system should make the park sustainable in the longer term.

\subsection{Problems identified in the park}

The history of this park shows that a number of identifiable problems arose almost immediately upon the park's opening. This was not a park that gradually declined over time. It declined immediately and critically.

The main problem was highlighted within four years of the park opening by Jackson [8]. The design stage never addressed the amount of expertise and 
resources that would be needed to maintain the park, especially the complex water features. The situation was further compounded by the death of a child soon after opening, which led to a decision not to maintain the water features [7]. As Pearson [9] points out, the death seemed, until at least 1999, to be the key factor that determined the non-intervention strategy which was adopted with regard to the water features.

The lack of sufficient expertise and resources impacted on other areas of the park. Trees were not thinned out when they should have been, so they became spindly and eventually dangerous, particularly so with the poplars. This led to an emergency remedial thinning and replacement programme in 2002.

The minimal maintenance programme seemed to be restricted to cutting the grass and clearing up litter [8] which meant that the wildlife value of the park suffered, and vandalism and quad bikes became a problem [4].

Many of these problems could probably have been identified at the planning stage, especially the resources and expertise needed to maintain the park, but it seems they were not. Furthermore, there was little evidence of any community consultation, which would undoubtedly have highlighted potential community concerns, such as vandalism and arson.

None of these problems were addressed for over 16 years until money became available to carry out a substantial remedial programme to correct the many potentially avoidable problems found in the park.

\section{Bow Creek Ecology Park}

\subsection{Developmental history}

Historical information is limited for the Bow Creek site. In 1805 the Limmo Peninsular was still wet marshland, but in the Victorian period it became a coal yard and a coal wharf for the Thames Ironworks and shipping company. This closed in 1912 and for 68 years Bow Creek became part of a railway marshalling yard [9]. On closure of the marshalling yards in 1970 the site remained derelict and unused until it was taken over, first by the Docklands Light Railway in 1991 to construct the line which cuts through the centre of the site, and then by the LDDC in 1994 who decided to develop the land as an Ecology Park and green space. When the LDDC was dissolved in 1998, the park was handed over to the Lee Valley Regional Park Authority (LVRPA) [9].

\subsection{Park development 1993-1998}

In 1993, the LDDC held a design competition which was won by Gibberd Landscape Design. The design philosophy was to utilise the already existing freshwater ponds that had naturally developed and create six different habitats. These would be connected via gravel paths and non-slip decking [10]. The new Ecology Park was to be primarily developed as an educational resource for school children so that they could see a number of different habitats within an urban area lacking in greenspace. The six habitats chosen were chalk grassland, 
willow coppice, mixed scrub, fen, ditches and ponds [10]. The wetland and water features were to be fed by a wind pump that pumped water into a tank and then through the park and habitats via constructed water conduits and sluices [10]. Construction began in 1994 and was completed in 1996. The park was managed by the Trust for Urban Ecology until 2002 [1].

\subsection{Park decline 1998-2000}

After the LVRPA took over responsibility for the park it was realised that there were a number of critical problems which resulted in closure of the park for health and safety reasons. As early as 1996, problems with water supply to the water features had been recognised. Dewhurst and Wurzell noted in their habitat survey report [11], that the newly installed wind pump to supply the water features had failed and that the park was having to be supplied by the river and rainwater runoff from the DLR viaduct. However, this was inadequate and the areas described as the pond and chalk channel, together with the willow coppice and water meadow were not being supplied with sufficient water and consequently were not developing as habitats in the way that was originally envisaged.

The 2002 LVRPA Management Plan [13] identified a number of critical problems that had arisen since 1998 leading to eventual closure. These were:

\subsubsection{Site infrastructure}

The Management Plan [13] highlighted design flaws and maintenance failings. Many of the channels used to move water around the park were subsiding through 'poor design'. The river edge fencing made of chestnut paling was prone to vandalism and did not reach health and safety standards. There was also a water wheel that served no purpose. The site infrastructure had deteriorated through bad design and maintenance and any site improvement programme 'would have to address its purpose, sustainability and durability issues'.

\subsubsection{Access}

The main access into and through the site was a gravel path with boardwalks connecting to the ecological zones. The gravel path was found to be suffering from encroachment by weeds and many of the boardwalks had deteriorated, were slippery or had been laid at the wrong angle. Furthermore, the access routes did not meet the requirements of the Disability Discrimination Act.

\subsubsection{Habitats and communities}

The report commented that:

'Due to the small size of the individual habitats, there is a problem with succession. Wetland habitats are also reliant on an artificial water supply. Poor design of the site has highlighted the fragility of the infrastructure in general, whilst the west shore suffers from tidal erosion. The site is affected by pollution through traffic congestion, factory emissions and water contamination. The site is also isolated and therefore vulnerable to vandalism.' 


\subsubsection{Public interest}

The report noted that while currently there was no public access because of the construction work at the entrance to the park, the future was more promising because of the comparative dearth of greenspace and open spaces for public use in the area. However, it noted that the park suffered in the past because there was never any provision for visitor facilities or interpretation boards.

\subsubsection{Education facilities}

The report found that the health and safety issues identified in two Risk Assessment reports in 1998 and 2002 meant that the park was inadequate by LVRPA standards for educational programmes. This was mainly because the site was isolated and difficult to access.

\subsection{The new development strategy for the park}

Following critical design and maintenance flaws that were identified in the Bow Creek management plan [13], it was decided that the park would need renovating and simplifying. This is an ongoing programme begun in 2003. Essentially, the water features have been simplified because the water is no longer pumped, so there is now only one pond with other wetland areas becoming naturally wet only in the winter. The sluice systems, waterwheel and wind pump have also been removed. The majority of the boardwalking was also removed except around the dipping pond. The old pathways have been removed and one main tarmac path, forming a loop around the two halves of the park, has been created to replace the several smaller gravel paths. Seating and fencing has been improved and is vandal resistant. Attempts to maintain six small complex ecosystems have been abandoned and all but one of the former pond areas have been allowed to develop along more natural lines. There has been some limited tree planting and some areas are cut as part of a wildflower meadow maintenance programme. There has also been some planting of marsh species in the flood hollows.

The aim of the new management regime has been to correct the flaws in the original design by either replacement or removal. Through adoption of a modest design and simplification of the park it is hoped that it will now be both financially and physically more sustainable.

\section{Discussion and conclusions}

There are a number of similarities between the factors leading to failings at the two parks. Firstly, no allowance was made at the design planning stage for financing the long-term management of the parks other than to hand them over to new management agencies who had had little influence over their design. In both cases, the LDDC chose very ambitious designs for the parks, which at best, would be very demanding and expensive to maintain. However, the parks were constructed without any analysis of actual resources available to maintain the parks once they were handed over $[1,7]$. The result was that the budget available 
to maintain each park was inadequate and the consequences were an almost immediate decline in park quality. The second similarity was that there was little public consultation over the original park designs. Had there been, then it is possible that less complex but more ecologically and financially sustainable designs may have been chosen at the beginning. The third similarity is that in order to be more sustainable, the parks needed to be regenerated and radically simplified. It would appear that there was confusion in the original design regarding the relative importance of naturalistic and artificial elements, and the interplay between them. There also appeared a worthy yet impracticable reliance on so-called 'green' solutions, such as the use of wind pump, which can be extremely difficult to manage and maintain in an urban setting. Ecology appears increasingly to be an important driver in urban greenspace design [13] but to be sustainable, areas designated within new urban greenspace projects must adhere to sound ecological principles.

In addition, deliberate construction of habitats ecologically alien to the surroundings will inevitably lead to larger maintenance demands. In this context, the ambitions of new 'Ecology Parks' must be tailored to the expectations of what resources will be available for maintenance. Educational extension services will also be necessary to gain the benefits implicit in Ecology Park construction. Public consultation will be essential to ensure that ecology is an important design driver for the new greenspace, as well as identifying the types of preferred habitats, and whether there is local expertise to support them, e.g. in a voluntary capacity. However, Russia Dock and Bow Creek are now success stories because eventually the problems identified above have been overcome through regeneration and redesign plans which included public consultation. The simplifying of the parks' aims and designs should mean that they are sustainable in the long term and will be a considerable greenspace asset to the surrounding communities for years to come.

The lessons to be learnt from these parks are that there should be a long-term financial and management strategy agreed at the time of the park planning and design stage so that the long-term sustainability of the parks, both financially and ecologically, can be assured. This should be achieved through public consultation, taking on board the views of the public, experts such as ecologists and the organisations that will need to maintain the parks post handover. It is only through doing this that a truly sustainable park design will result that will be an asset to the community over the long term.

\section{Acknowledgements}

We thank the EPSRC, who funded this research work as part of the SUBR:IM consortium under Grant GR/S148809/01. We also thank Gez Breed at the LVRPA and Jon Best at the London Borough of Southwark for providing their help, advice, information and time. 


\section{References}

[1] Dewhurst, B. Personal communication, 17 March 2006, Chief Executive, Trust for Urban Ecology. UK.

[2] Watts, K. Personal communication ,16 March 2006, Landscape Ecologist, Forest Research UK.

[3] A Management Strategy for Russia Dock Woodlands, Voelcker Consultants, London UK, 2002.

[4] Best, J. Personal communication 26 April 2005, Ecologist, London Borough of Southwark, London UK.

[5] An investigation of the acceptability of the education and recreational use of the Limmo Nature Park by children, Clayton Environmental Consultants Ltd. Ilford, UK, 1994.

[6] Surrey Docks, LDDC Completion Booklets; London Docklands Development Corporation

[7] www.lddc-history.org.uk/surrey/index.html\#History

[8] Jackson, P. Landscape as a catalyst. Landscape Design, 163 (October), pp 38-41, 1986

[9] Pearson, M. A landscape assessment: Russia Dock water feature. Thesis, Advanced Diploma in Arboriculture and Community Forest Management, Middlesex University, 1999.

[10] Breed, G. Personal communication 15 April 2004 Ranger Lee Valley Parks Authority. London UK.

[11] Landscape developments at Limmo Peninsular, London Docklands Development Corporation, 1995.

[12] Bow Creek Ecology Park, The Bird Sanctuary and East India Dock Basin habitat survey, London Docklands Development Corporation, 1996.

[13] Bow Creek Management Plan 2002 -2005, Lee Valley Park Authority, 2002.

[14] Crystal Palace Park. Public Consultation. The report, the results , 2002. 